\title{
Effect of Adding Phosphorous With Organic Matter on Wheat Production under Sandy Soil Conditions
}

\author{
Esmat H.A. Noufal, Raafat Sorour El-Sayed Abdel-Aal, Farag A. Al-Qased, Ibrahim M. El-Sayed Ali and \\ Hassan M. M. M. \\ *Corresponding author: essmat.nofal@fagr.bu.edu.eg
}

\begin{abstract}
Wheat is one of the most important strategic crops in terms of food security. Phosphorus (P) is an essential macronutrient being required by plants in relatively large amounts. The availability of phosphorus in soils is affected by several factors such as the decomposition of organic matter in the soil. Higher soil organic matter concentrations have been proved to enhance the yield and yield components of cereals. The present study, therefore, aims at studying the effect of adding phosphorus and farmyard manure as a source of organic matter on the yield of wheat plants grown under sandy soils conditions. To fulfill the objective of the study a field experiment was conducted at Balouza station in North Sinai, Desert Land Research Center, in the winter season 2018-2019. The design of the experiment was a factorial randomized complete block design with two factors in three replicates. The experimental site was divided into two main plots. Each main plot was divided into three subplots. Organic manure was added to the first half of the main plots at a rate of $25 \mathrm{~kg} / \mathrm{plot}, \mathrm{O} 1$ ( $25 \mathrm{ton} / \mathrm{hectare}$ ) and at a rate of $50 \mathrm{~kg} / \mathrm{plot} \mathrm{O}_{2}(50 \mathrm{ton} / \mathrm{hectare})$ to the other half. Superphosphate was added at three rates i.e P1 = 840 $\mathrm{kg} /$ hectare superphosphate fertilizer $(6.8 \% \mathrm{P})$. as soil application; $\mathrm{P} 2=630 \mathrm{~kg} /$ hectare superphosphate fertilizer as soil application $+210 \mathrm{~kg} /$ hectare superphosphate fertilizer as foliar application and P3 $=420 \mathrm{~kg} / \mathrm{hectare}$ superphosphate fertilizer as soil application $+420 \mathrm{~kg} / \mathrm{hectare}$ superphosphate fertilizer as foliar application. Each treatment was replicated three times. The foliar application was done as the supernatant of soaked superphosphate fertilizer.
\end{abstract}

Wheat grains (cv. Giza 168) was cultivated in 23 November 2018. Irrigation was done with Al-Salam Canal water. At maturity (9/5/2019) wheat plants were harvested and separated into grains and straw. The grain yield and the straw yield was recorded. Subsamples of wheat straw and grains were ground. A 0.5 gram samples was digested using a mixture of sulphuric and perchloric acids (1:1 v/v). Digests were diluted with distilled water up to a $100 \mathrm{ml}$ and analyzed for $\mathrm{N}, \mathrm{P}$ and $\mathrm{K}$ concentration. The obtained results could be summarized as follows: There was a significant difference in grain yield due to the application of organic manure at increased rate from $\mathrm{O} 1$ to $\mathrm{O} 2$. Also, a significant difference in grain yield occurred due to the application of $\mathrm{P}$ fertilizer at increased rate from $\mathrm{P} 1$ to $\mathrm{P} 3$, and the rate $\mathrm{P} 2$ gave the highest increase. The interaction effect between the organic manure rate and $\mathrm{P}$ fertilizer rate was significant, where a significant difference in grain yield occurred between $\mathrm{P} 2$ application and the grain yield obtained due the application of P1 and P3 under the application of organic manure at the rate $\mathrm{O} 1$. Under the application of organic manure at the rate $\mathrm{O} 2$ significant difference in wheat grain yield occurred between P1,P2 and P3, however, the highest grain yield was obtained under the application of P at the rate $\mathrm{P} 2$ with the application of the organic manure at the rate $\mathrm{O} 2$.

There was a significant difference in straw yield obtained under the application of organic manure at increased and the highest straw yield was obtained at the rate $\mathrm{O} 2$. On the other hand, application of $\mathrm{P}$ fertilizer at increased rate significantly increased straw yield from P1application up to P2 application. However, increasing P application from P2 up to P3 decreased wheat straw yield. There was a significant interaction between the organic manure and $\mathrm{P}$ fertilizer on the straw yield of wheat, where a significant difference occurred between the straw yield obtained due to the application of $\mathrm{P}$ at increased rate from $\mathrm{P} 1$ up to $\mathrm{P} 3$ under the application of organic manure at the rates $\mathrm{O} 1(25$ ton/hectare) and $\mathrm{O} 2$ (50 ton/hectare). However the highest straw yield was obtained under the application of $\mathrm{P}$ fertilizer at the rate $\mathrm{P} 2$ and the application of organic manure at the rate $\mathrm{O} 2$.

Application of $\mathrm{P}$ fertilizer at increased rate under the application of organic manure at increased rate, increased the concentration of N, P and $\mathrm{K}$ in both of the straw and grains of wheat plants and the highest increase was obtained under the application of $\mathrm{P}$ fertilizer at the rate $\mathrm{P} 2$ and the application of organic manure at the rate $\mathrm{O} 2$.

Key words: Phosphorous, Wheat, Organic, Sandy Soil Conditions

\section{Introduction}

Wheat is one of the most important strategic crops in terms of food security. Phosphorus (P) is an essential macronutrient being required by plants in relatively large amounts. Its primary role in plant is to store and transfer energy produced by photosynthesis for use in growth and reproductive processes. The availability of phosphorus in soils is affected by several factors such as soil $\mathrm{pH}$, clay and sesquioxide content, and exchangeable $\mathrm{Al}_{3}{ }^{+}$content (White, 2006) and the decomposition of organic matter in the soil and activities of microorganisms (Brady and Weil,1999), soil water conditions and soil temperature (Sanchez,2007). The application of farmyard manure to the soils led to improving soil chemical, physical 
and biologicel properties (Belay et al., 2001). Soil $\mathrm{pH}$ values fell by one degree as result of adding farmyard manure due to the decomposition and mineralization of organic matter (Singh et al., 1980). Organic matter in soil improves soil structures, holding capacity and nutrient retention, aeration, soil moisture water infiltration (Deksissa et al., 2008). No doubt, that the chemical fertilizers are richer in their nutrient contents, less bulky, easier to transport and apply in the field, thus show quick response on crop in term of grain yield (Hussain et al., 1987). Due to larger consumption of chemical fertilizers, these are becoming expensive due to elimination of ubsidy, more dependent on chemical fertilizers for higher grain yield, declining efficiency of fertilizers and mismanagement of fertilizers at farm level. The nitrogenous fertilizers are lost in the form of ammonia volatilization violation and excessive leaching in the form of nitrates and fixation of larger portion of phosphorus may affect the environment (Maynard,1993). Higher soil organic matter concentrations have been proved to enhance the yield and yield components of cereals (Sarwar, 2005) as well as soil aeration, soil density and maximizing water holding capacity of soil for seed germination and plant root development (Zia et al., 1998). Since phosphate is highly immobile in soil, diffusion is the main way that phosphate anions can reach the root surface (Lambers et al. 2008). Although the diffusion coefficient of phosphate in the soil is much less than that of other nutrients, the diffusion can be increased by increasing the phosphate concentration in the soil solution (Lambers et al. 2006).

The application of organic manure with phosphatic fertilizers is considered a possible mean of mobilizing $\mathrm{P}$ because of the acidic environment generated during the decomposition of the manure. The different types of organic manure increase the microorganisms, release acids in the root rhizosphere and may help to solubilize $\mathrm{P}$ and to increase $\mathrm{P}$ availability to the plants . Thus, The present study, aims at studying the effect of adding phosphorus with farmyard manure as a source of organic matter on the growth and yield of wheat plants grown under sandy soils conditions.

\section{Material and Methods}

A field experiment was conducted at Balouza station in North Sinai, Desert Land Research Center, to study the effect of adding phosphate fertilizer with organic manure on wheat production under sandy soil conditions during the winter season 2018-2019.

\section{The experimental work:}

The experiment was conducted on a total area of three kirat divided into two main plots, then each main plot was divided into three subplots. Table 1 show some properties of the experimental soil. The area of each plot was $11 \mathrm{~m}^{2}$. Organic manure was added to the first half of plots at a rate of $25 \mathrm{~kg} /$ plot, 01 (equivalent to $25 \mathrm{ton} /$ hectare) and at a rate of $\mathbf{5 0}$ $\mathrm{kg} / \mathrm{plot}, \mathrm{O2}$ (equivalent to $50 \mathrm{ton} / \mathrm{hectare}$ ) to the other half. Table 2 show some characteristics of the organic manure used in the study. Superphosphate was added to each of the sub main plots at three rates i.e $\mathrm{P} 1=\mathbf{0 . 9 2 4} \mathrm{kg}$ superphosphate $(6.8 \% \mathrm{P}) / \mathrm{plot}$ equivalent to $100 \%$ of the P-fertilizer requirements for wheat plants $(840 \mathrm{~kg} /$ hectare $)$ as soil application; $\mathbf{P 2}=0.693 \mathrm{~kg}$ superphosphate /plot equivalent to $75 \%$ of the P-fertilizer requirements for wheat plants $(630 \mathrm{~kg} /$ hectare $)$ applied as soil application $+210 \mathrm{~kg}$ /plot equivalent to $25 \%$ of $P$ fertilizer requirements for wheat plants applied as foliar application and $\mathbf{P 3}=$ $0.462 \mathrm{~kg}$ superphosphate /plot equivalent to $50 \%$ of the P-fertilizer requirements for wheat plants $\mathbf{( 4 2 0}$ $\mathbf{k g} / \mathbf{h e c t a r e )}$ applied as soil application $+\mathbf{0 . 4 6 2} \mathbf{~ k g}$ superphosphate /plot equivalent to $50 \%$ of the Pfertilizer requirements for wheat plants applied as foliar application. The soil application of P-fertilizer was done during the preparation of the soil for sowing, while the foliar application was done on four doses; the first after 25 days, the second after 45 days, the third after 65 days and the fourth after 90 days from sowing. The foliar application was done as the supernatant of soaked superphosphate fertilizer.

The design of the experiment was a factorial randomized complete block design with two factors in three replicates as follows:

Factor A: Phosphate fertilizer (P) applied at three rates as follows:

$\mathrm{P} 1=0.924 \mathrm{~kg}$ P-fertilizer/plot applied as soil application

$\mathrm{P} 2=0.693 \mathrm{~kg} \mathrm{P}$-fertilizer/plot applied as soil application and $0.231 \mathrm{~kg}$ P-fertilizer /plot applied as foliar application

$\mathrm{P} 3=0.462 \mathrm{~kg}$ P-fertilizer $/$ plot applied as soil application $\mathrm{P}$ and $0.462 \mathrm{~kg}$ P-fertilizer /plot applied as foliar application

Factor B: Organic manure $(\mathrm{O})$ applied at two rates as follows:

$\mathrm{O} 1=25 \mathrm{~kg}$ organic manure $/$ plot (25 ton/hectare)

$\mathrm{O} 2=50 \mathrm{~kg}$ organic manure $/$ plot (50 ton/hectare)

Each treatment was replicated three times, hence, the total number of the experimental treatments plots was: $2 \mathrm{O} \times 3 \mathrm{P} \times 3$ replicates $=18$ plots. 
Table 1. Soil physical and chemical properties.

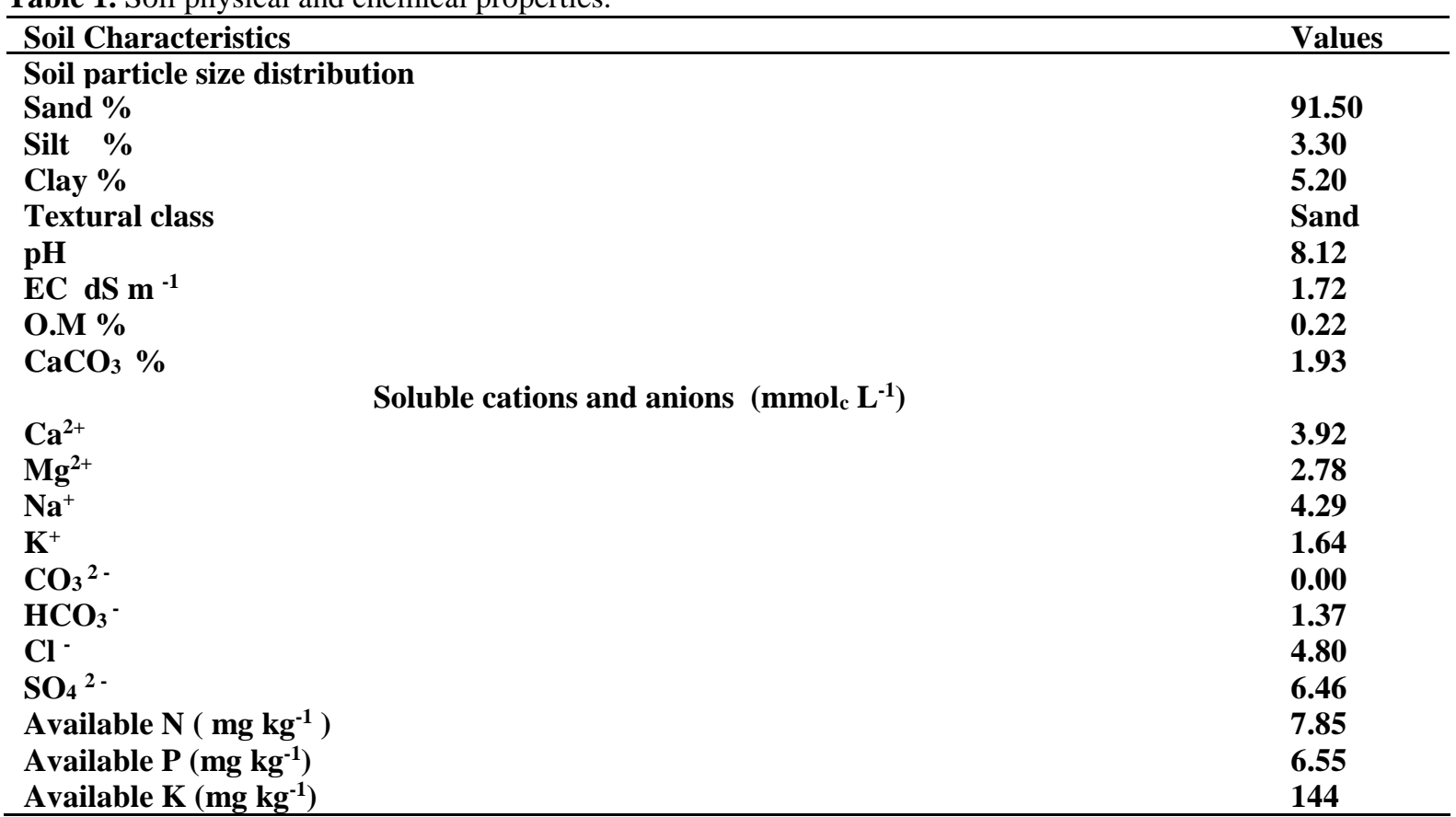

Table 2. Some characteristics of the organic manures used in the study.

\begin{tabular}{ccccccccc}
\hline $\begin{array}{c}\text { Organic } \\
\text { manure }\end{array}$ & $\begin{array}{c}\mathbf{E C} \\
\mathbf{d S m}^{-1}\end{array}$ & $\mathbf{p H}$ & $\begin{array}{c}\text { Organic } \\
\text { carbon }\end{array}$ & $\begin{array}{c}\mathbf{C} / \mathbf{N} \\
\text { Ratio }\end{array}$ & $\begin{array}{c}\text { Humidity } \\
\mathbf{\%}\end{array}$ & $\begin{array}{c}\mathbf{N} \\
\mathbf{\%}\end{array}$ & $\begin{array}{c}\mathbf{P} \\
\mathbf{\%}\end{array}$ & $\begin{array}{c}\mathbf{K} \\
\mathbf{\%}\end{array}$ \\
\hline $\begin{array}{c}\text { Farm yard } \\
\text { manure }\end{array}$ & 3.35 & 8.5 & 20.6 & 12.5 & 10 & 2.25 & 0.55 & 0.60 \\
\hline
\end{tabular}

Wheat grains (Triticum aestivum L.cv. Giza 168) was cultivated in 23 November 2018. During the growth season, nitrogen fertilizer was added on 3 doses according to the recommended dose at a rate of $450 \mathrm{~kg}$ / hectare as ammonium sulfate (20\% at sowing, $40 \%$ with the first irrigation and $40 \%$ with the second irrigation). Also, $\mathrm{K}$ fertilizer was added, at three doses in the form of potassium sulphat at a rate of 300 $\mathrm{kg} /$ hectare. The first dose was added after 25 days, the second dose after 45 days and the third after 65 days from sown. Irrigation was done with Al-Salam Canal water, which is a mixed water of the Nile water and agricultural drainage water at a ratio of 1:1. Table 3 show the chemical analysis of Al-Salam water which was done according to the standard method cited by Page (1982).

Table 3. Chemical analysis of the water used in irrigation

\begin{tabular}{|c|c|c|c|c|c|c|c|c|c|c|}
\hline \multirow{2}{*}{$\mathbf{p H}$} & \multirow{2}{*}{$\begin{array}{c}\mathrm{EC} \\
\left(\mathrm{dSm}^{-1}\right)\end{array}$} & \multirow{2}{*}{$\begin{array}{c}\text { TDS } \\
(\mathrm{mg} / \mathrm{L})\end{array}$} & \multicolumn{4}{|c|}{ Cations (meq/L) } & \multicolumn{4}{|c|}{ Anions (meq/L) } \\
\hline & & & $\mathrm{Ca}^{2+}$ & $\mathrm{Mg}^{2+}$ & $\mathbf{N a}^{+}$ & $\mathbf{K}^{+}$ & $\mathrm{CO}_{3}^{-}$ & $\mathrm{HCO}_{3}^{-}$ & $\mathrm{Cl}^{-}$ & $\mathrm{SO}_{4}{ }^{2-}$ \\
\hline 7.81 & 2.96 & 1609.70 & 4.31 & 4.45 & 11.87 & 0.28 & -- & 5.3 & 10.95 & 4.66 \\
\hline
\end{tabular}

At maturity wheat plants were harvested on 9/5/2019 and separated into grains and straw. The grain yield and the straw yield was recorded. Subsamples of wheat straw and grains were dried and ground. A 0.5 gram samples was digested using a mixture of sulphuric and perchloric acids $(1: 1 \mathrm{v} / \mathrm{v})$ as reported by Chapman and Pratt (1961). Digests were diluted with distilled water up to a $100 \mathrm{ml}$ according to Page (1982) and analyzed for N, P and K content $(\%)$.

\section{Results and Dissection}

Results in Table $4 \mathbf{A}$ and $\mathbf{B}$ show the effect of adding P-fertilizer with organic manure on the grain and straw yield of wheat plants growing on studied sandy soil.

\section{Effect on straw yield}

The obtained results (Table 4A)show that increasing the P-fertilizer application increased wheat grain yield specially under the high rate of organic manure application $(\mathrm{O} 2,50$ ton/hectare $)$. However, 
the highest increase was obtained under the application of the rate $\mathrm{P} 2=630 \mathrm{~kg}$ superphosphate/hectare which equivalent to $75 \%$ of the P-fertilizer requirements for wheat plants applied as soil application $+0.210 \mathrm{~kg} /$ hectare which equivalent to $25 \%$ of $\mathrm{P}$ fertilizer requirements for wheat plants applied as foliar application. There was a significant difference in grain yield obtained due to the application of organic manure at increased rate from $\mathrm{O} 1$ to $\mathrm{O} 2$. Also, a significant difference in grain yield occurred due to the application of $P$ fertilizer at increased rate from $\mathrm{P} 1$ to $\mathrm{P} 3$, and the rate $\mathrm{P} 2$ gave the highest yield. The interaction effect between the organic manure rate and P-fertilizer rate was significant where a significant difference occurred between the grain yield obtained due to P2 application and the grain yield obtained due the application of each of P1 and P3 under the application of organic manure at the rate $\mathrm{O} 1$. Under the application of organic manure at the rate $\mathrm{O} 2$ significant difference in wheat grain yield occurred among P1,P2 and P3, however, the highest grain yield was obtained under the application of $\mathrm{P}$ at the rate $\mathrm{P} 2$.

\section{Effect on straw yield}

Concerning the straw yield, the obtained results in Table 4B show that application of the organic manure at increased rate significantly increased wheat straw yield specially under the application of the rate $\mathrm{O} 2(50$ ton/hectare) where the highest straw yield was obtained. On the other hand, application of P-fertilizer at increased rate from $\mathrm{P} 1$ up to $\mathrm{P} 2$ significantly increased straw yield. However, increasing $P$ application rate from $\mathrm{P} 2$ up to $\mathrm{P} 3$ decreased wheat straw yield.

There was a significant interaction between the organic manure application rate and the P-fertilizer application rate on the straw yield of wheat, where a significant difference occurred between the straw yield obtained due to the application of P-fertilizer at increased rate from P1 (840 kg/hectare) up to P3 (420 $\mathrm{kg} \mathrm{p} /$ hectare as soil application $+420 \mathrm{~kg}$ p/hectare as foliar application) under the application of organic manure at the rates $\mathrm{O} 1(25 \mathrm{ton} / \mathrm{hectare})$ and $\mathrm{O} 2$ (50 ton/hectare). However the highest straw yield was obtained under the application of $\mathrm{P}$ fertilizer at the rate P2 (630 kg P-fertilizer/hectare as soil application + $210 \mathrm{~kg}$ P-fertilizer/hectare as foliar application) and the application of organic manure at the rate $\mathrm{O} 2(50$ ton/hectar).

Table 4. Effect of application of P-fertilizer with organic manure on the yield of wheat grown on the sandy soil under study.

$\underline{\text { A:Grain yield (mean } \pm \text { SE). }}$

\begin{tabular}{|c|c|c|c|c|}
\hline \multirow{2}{*}{$\begin{array}{c}\text { Factor }(\mathrm{A}) \\
\text { Organic manure } \\
\text { rate }\end{array}$} & \multirow{2}{*}{\multicolumn{3}{|c|}{$\begin{array}{c}\text { Factor }(B) \\
\text { Phosphorus fertilizer rate }\end{array}$}} & \multirow{2}{*}{ Mean } \\
\hline & & & & \\
\hline O1 & $5016 \pm 56.58^{\text {bB }}$ & $5622 \pm 71.56^{\mathrm{bA}}$ & $5046 \pm 106.40^{\mathrm{bB}}$ & $5228 \pm 106.5^{b}$ \\
\hline $\mathbf{O 2}$ & $5209 \pm 56.00^{\mathrm{aC}}$ & $5993 \pm 57.04^{\mathrm{aA}}$ & $5623 \pm 58.08^{\mathrm{aB}}$ & $5608 \pm 116.67^{a}$ \\
\hline Mean & $5113 \pm 56.00^{\mathrm{C}}$ & $5807 \pm 92.50^{A}$ & $5335 \pm 139.95^{\mathrm{B}}$ & \\
\hline \multirow{2}{*}{\multicolumn{2}{|c|}{ LSD at 0.05 for }} & $\mathbf{O}$ & $\mathbf{P}$ & $\mathbf{O} * \mathbf{P}$ \\
\hline & & 124.56 & 152.55 & 215.74 \\
\hline
\end{tabular}

B: Straw yield (mean \pm SE).

\begin{tabular}{|c|c|c|c|c|}
\hline \multirow{2}{*}{$\begin{array}{c}\text { Factor (A) } \\
\text { Organic manure } \\
\text { rate }\end{array}$} & \multirow{2}{*}{\multicolumn{3}{|c|}{$\begin{array}{c}\text { Factor (B) } \\
\text { Phosphorus fertilizer rate }\end{array}$}} & \multirow{2}{*}{ Mean } \\
\hline & & & & \\
\hline 01 & $8104 \pm 33.88^{b C}$ & $8743 \pm 25.31^{\text {bA }}$ & $8316 \pm 107.33^{b B}$ & $8388 \pm 99.60^{b}$ \\
\hline $\mathbf{O 2}$ & $9039 \pm 51.12^{\mathrm{aB}}$ & $9651 \pm 66.00^{\mathrm{aA}}$ & $8576 \pm 164.47^{\mathrm{aC}}$ & $9089 \pm 164.56^{a}$ \\
\hline Mean & $8572 \pm 210.79^{B}$ & $9197 \pm 205.63^{A}$ & $8446 \pm 105.37^{B}$ & \\
\hline \multirow{2}{*}{\multicolumn{2}{|c|}{ LSD at 0.05 for }} & $\mathbf{O}$ & $\mathbf{P}$ & $\mathbf{O} * \mathbf{P}$ \\
\hline & & 158.01 & 193.53 & 273.69 \\
\hline
\end{tabular}

a, b \& c: There is no significant difference $(\mathrm{P}>0.05)$ between any two means, within the same column have the same superscript letter.

A, B \& C: There is no significant difference $(\mathrm{P}>0.05)$ between any two means for the same attribute, within the same row have the same superscript letter.

\section{Effect on nutrient content (\%)}

Results in Tables and 6 show the effect of adding P-fertilizer with organic manure on nutrients $(\mathrm{N}, \mathrm{P}$ and $\mathrm{K})$ content in the grains and straw of wheat plants, respectively, growing on studied sandy soil.

As for $\mathrm{N}, \mathrm{P}$ and $\mathrm{K}$ content $(\%)$ in the wheat grains, results in Table $5 \mathbf{A}, \mathbf{B}$ and $\mathbf{C}$ show that application of $\mathrm{P}$ fertilizer at increased rate with the application of organic manure at increased rate, significantly increased the concentration of $\mathrm{N}, \mathrm{P}$ and $\mathrm{K}$ in grains of wheat plants and the highest increase was obtained under the application of P-fertilizer at the rate $\mathrm{P} 2$ with the application of organic manure at the rate $\mathrm{O} 2$. Also, application of organic manure 
significantly increased $\mathrm{N}, \mathrm{P}$ and $\mathrm{K}$ concentration specially with the application at the rate $\mathrm{O} 2$ where a significant difference occurred between $\mathrm{N}, \mathrm{P}$ and $\mathrm{K}$ (\%) obtained due to the application of organic manure by the rate $\mathrm{O} 2$ and that obtained due the application by the rate $\mathrm{O} 1$.

The interaction effect between $\mathrm{P}$ - fertilizer application rate and the organic manure application rate (Table 5A, $\mathbf{B}$ and $\mathbf{C}$ ) show that there were significant differences in $\mathrm{N}, \mathrm{P}$ and $\mathrm{K}$ contents $(\%)$ between the three rates of $\mathrm{P}$-fertilizer application with the organic manure application rate. In the case of $\mathrm{N}$ $\%$, significant difference occurred only between P2 and each of P1 and P3 when organic manure was applied at the rate $\mathrm{O} 1$ while significant difference occurred only between $\mathrm{P} 2$ and P3 when organic manure was applied at the rate $\mathrm{O} 2$. In the case of $\mathrm{P}$ content $(\%)$ significant difference occurred between P2 and each of P1 and P3 under the application of organic manure at the rate $\mathrm{O} 1$ whereas significant difference occurred between P2 and P1 only when organic manure was added at the rate $\mathrm{O} 1$. However the highest $\mathrm{P}$ content (\%) was obtained under the application of $\mathrm{P}$-fertilizer by the rate $\mathrm{P} 2$ with the organic manure by the rate $\mathrm{O} 2$. With respect to $\mathrm{K}$ content $(\%)$ results show that the interaction effect between $\mathrm{P}$-fertilizer rate and organic manure rate on $\mathrm{K}$ (\%) tack a trend almost similar to that obtained with N.

Table 5. Effect of application of P-fertilizer with organic manure on the $\mathrm{N}, \mathrm{P}$ and $\mathrm{K}$ contents (\%) in grains of wheat plants grown on the sandy soil under study. A: $N \%($ mean \pm SE).

\begin{tabular}{|c|c|c|c|c|}
\hline \multirow{2}{*}{$\begin{array}{c}\text { Factor }(\mathrm{A}) \\
\text { Organic manure } \\
\text { rate }\end{array}$} & \multicolumn{3}{|c|}{$\begin{array}{c}\text { Factor }(B) \\
\text { Phosphorus Fertilizer rate }\end{array}$} & \multirow[t]{2}{*}{ Mean } \\
\hline & P1 & $\mathbf{P 2}$ & P3 & \\
\hline $\mathbf{0 1}$ & $15.43 \pm 0.23^{\mathrm{bB}}$ & $16.37 \pm 0.29^{\mathrm{bA}}$ & $14.93 \pm 0.44^{\mathrm{aB}}$ & $15.58 \pm 0.27^{b}$ \\
\hline $\mathbf{O 2}$ & $16.37 \pm 0.29^{\mathrm{aA}}$ & $17.00 \pm 0.25^{\mathrm{aA}}$ & $15.43 \pm 0.23^{\mathrm{aB}}$ & $16.27 \pm 0.26^{\mathrm{a}}$ \\
\hline Mean of OM & $15.90 \pm 0.27^{\mathrm{B}}$ & $16.68 \pm 0.22^{\mathrm{A}}$ & $15.18 \pm 0.25^{\mathrm{C}}$ & \\
\hline \multirow{2}{*}{\multicolumn{2}{|c|}{ LSD at 0.05 for }} & $\mathbf{O}$ & $\mathbf{P}$ & $\mathbf{O} * \mathbf{P}$ \\
\hline & & 0.53 & 0.65 & 0.92 \\
\hline
\end{tabular}

B: P \% (mean \pm SE).

\begin{tabular}{|c|c|c|c|c|}
\hline \multirow{2}{*}{$\begin{array}{c}\text { Factor }(\mathrm{A}) \\
\text { Organic manure } \\
\text { rate }\end{array}$} & \multicolumn{3}{|c|}{$\begin{array}{c}\text { Factor }(\mathbf{B}) \\
\text { Phosphorus Fertilizer rate }\end{array}$} & \multirow{2}{*}{ Mean } \\
\hline & P1 & $\mathbf{P 2}$ & $\mathbf{P 3}$ & \\
\hline O1 & $9.27 \pm 0.45^{\mathrm{bB}}$ & $11.10 \pm 0.44^{\mathrm{bA}}$ & $9.87 \pm 0.57^{\mathrm{bB}}$ & $10.08 \pm 0.36^{b}$ \\
\hline $\mathbf{O 2}$ & $11.23 \pm 0.28^{\mathrm{aB}}$ & $12.73 \pm 0.43^{\mathrm{aA}}$ & $12.33 \pm 0.67^{\mathrm{aA}}$ & $12.10 \pm 0.33^{a}$ \\
\hline Mean & $10.25 \pm 0.50^{B}$ & $11.92 \pm 0.46^{\mathrm{A}}$ & $11.10 \pm 0.68^{\mathrm{AB}}$ & \\
\hline \multirow{2}{*}{\multicolumn{2}{|c|}{ LSD at 0.05 for }} & $\mathbf{O}$ & $\mathbf{P}$ & $\mathbf{O} * \mathbf{P}$ \\
\hline & & 0.87 & 1.06 & 1.50 \\
\hline
\end{tabular}

$\mathrm{C}: \mathrm{K} \%(\operatorname{mean} \pm \mathrm{SE})$.

\begin{tabular}{|c|c|c|c|c|}
\hline \multirow{2}{*}{$\begin{array}{c}\text { Factor }(\mathrm{A}) \\
\text { Organic manure } \\
\text { rate }\end{array}$} & \multicolumn{3}{|c|}{$\begin{array}{c}\text { Factor }(B) \\
\text { Phosphorus Fertilizer rate }\end{array}$} & \multirow{2}{*}{ Mean } \\
\hline & $\overline{\text { P1 }}$ & P2 & $\overline{\text { P3 }}$ & \\
\hline O1 & $7.37 \pm 0.12^{\mathrm{bB}}$ & $8.40 \pm 0.17^{\mathrm{aA}}$ & $7.53 \pm 0.03^{\mathrm{bB}}$ & $7.77 \pm 0.17^{b}$ \\
\hline $\mathbf{O 2}$ & $7.93 \pm 0.09^{\mathrm{aB}}$ & $8.53 \pm 0.09^{\mathrm{aA}}$ & $8.13 \pm 0.18^{\mathrm{aB}}$ & $8.20 \pm 0.11^{\mathrm{a}}$ \\
\hline Mean & $7.65 \pm 0.14^{B}$ & $8.47 \pm 0.09^{A}$ & $7.83 \pm 0.16^{B}$ & \\
\hline \multirow{2}{*}{\multicolumn{2}{|c|}{ LSD at 0.05 for }} & $\mathbf{O}$ & $\mathbf{P}$ & $\mathbf{O} * \mathbf{P}$ \\
\hline & & 0.22 & $\mathbf{0 . 2 7}$ & $\mathbf{0 . 3 8}$ \\
\hline
\end{tabular}

a, b \& c: There is no significant difference $(\mathrm{P}>0.05)$ between any two means, within the same column have the same superscript letter.

A, B \& C: There is no significant difference $(\mathrm{P}>0.05)$ between any two means for the same attribute, within the same row have the same superscript letter.

Concerning the effect on $\mathrm{N}, \mathrm{P}$ and $\mathrm{K}$ content (\%) in the straw of wheat plants, results in Table $6 \mathrm{~A}, \mathrm{~B}$ and $\mathrm{C}$ show that application of $\mathrm{P}$-fertilizer with the organic manure at increased rates significantly increased $\mathrm{N}$ content with increasing the P-fertilizer application rate up to $\mathrm{P} 3$ and the highest $\mathrm{N}$ content ( $\%$ ) was obtained under the $\mathrm{P} 2$, while $\mathrm{P} \%$ and $\mathrm{K} \%$ increased with increasing P-fertilizer application rate up to P2 then decreased with increasing P-fertilizer rate up to $\mathrm{P} 3$. However, the highest $\mathrm{P}$ and $\mathrm{K}$ content obtained under the P-fertilizer application rate P3. Significant difference in $\mathrm{P} \%$ occurred only between the rate $\mathrm{P} 2$ and the rate $\mathrm{P} 3$ whereas no significant difference occurred between the three rates of $\mathrm{P}$ - 
fertilizer application in case of $\mathrm{K}$ content $(\%)$. No significant differences in $\mathrm{P} \%$ and $\mathrm{K} \%$ in wheat straw occurred due to the application of organic manure at the rate $\mathrm{O} 1$ or $\mathrm{O} 2$

Concerning the interaction effect between Pfertilizer application rate and organic manure application rate on the $\mathrm{N}, \mathrm{P}$ and $\mathrm{K}$ content $(\%)$ in wheat straw, the obtained results show that significant interaction occurred only on $\mathrm{N}$ content $(\%)$. Where, under the application of organic manure at the rate $\mathrm{O} 1$ significant difference in $\mathrm{N} \%$ occurred only between P2 and each of P1 and P3; in case of application of the organic manure by the rate of $\mathrm{O} 2$ significant differences occurred between the three rates of $\mathrm{P}$ fertilizer application and the highest $\mathrm{N} \%$ was obtained under the application of P-fertilizer at P3 and the organic manure at the rate $\mathrm{O} 2$.

Table 6. Effect of application of P-fertilizer with organic manure on the N, P and K contents (\%) in the straw of wheat plants grown on the sandy soil under study.

$\mathrm{A}: \mathbf{N}(\mathbf{m e a n} \pm \mathrm{SE})$.

\begin{tabular}{|c|c|c|c|c|}
\hline \multirow{2}{*}{$\begin{array}{c}\text { Factor }(\mathrm{A}) \\
\text { Organic manure } \\
\text { rate }\end{array}$} & \multicolumn{3}{|c|}{$\begin{array}{c}\text { Factor }(\mathbf{B}) \\
\text { Phosphorus Fertilizer rate }\end{array}$} & \multirow[t]{2}{*}{ Mean } \\
\hline & P1 & P2 & P3 & \\
\hline O1 & $7.50 \pm 0.06^{b B}$ & $9.87 \pm 0.22^{b A}$ & $7.70 \pm 0.06^{\mathrm{bB}}$ & $8.36 \pm 0.38^{b}$ \\
\hline $\mathbf{O 2}$ & $7.80 \pm 0.06^{\mathrm{aC}}$ & $11.57 \pm 0.20^{\mathrm{aA}}$ & $9.00 \pm 0.06^{\mathrm{aB}}$ & $9.46 \pm 0.56^{a}$ \\
\hline Mean & $7.65 \pm 0.08^{C}$ & $10.72 \pm 0.40^{\mathrm{A}}$ & $8.35 \pm 0.29^{B}$ & \\
\hline \multirow{2}{*}{\multicolumn{2}{|c|}{ LSD at 0.05 for }} & $\mathbf{O}$ & $\mathbf{P}$ & $\mathbf{O} * \mathbf{P}$ \\
\hline & & 0.23 & 0.28 & 0.40 \\
\hline
\end{tabular}

B: P $($ mean \pm SE).

\begin{tabular}{|c|c|c|c|c|}
\hline \multirow{2}{*}{$\begin{array}{c}\text { Factor }(\mathrm{A}) \\
\text { Organic manure } \\
\text { rate }\end{array}$} & \multicolumn{3}{|c|}{$\begin{array}{c}\text { Factor }(B) \\
\text { Phosphorus Fertilizer rate }\end{array}$} & \multirow{2}{*}{ Mean } \\
\hline & P1 & $\mathbf{P 2}$ & $\overline{\text { P3 }}$ & \\
\hline O1 & $10.00 \pm 0.61^{\mathrm{aAB}}$ & $11.20 \pm 0.61^{\mathrm{aA}}$ & $8.80 \pm 0.00^{b B}$ & $10.00 \pm 0.43^{a}$ \\
\hline $\mathbf{O 2}$ & $10.40 \pm 0.83^{\mathrm{aA}}$ & $11.60 \pm 0.83^{\mathrm{aA}}$ & $10.40 \pm 0.61^{\mathrm{aA}}$ & $10.80 \pm 0.43^{\mathrm{a}}$ \\
\hline Mean & $10.20 \pm 0.47^{\mathrm{AB}}$ & $11.40 \pm 0.47^{\mathrm{A}}$ & $9.60 \pm 0.45^{B}$ & \\
\hline \multirow{2}{*}{\multicolumn{2}{|c|}{ LSD at 0.05 for }} & $\mathbf{O}$ & $\mathbf{P}$ & $\mathbf{O} * \mathbf{P}$ \\
\hline & & 1.15 & 1.41 & 1.99 \\
\hline
\end{tabular}

$\mathrm{C}: \mathrm{K}($ mean $\pm \mathrm{SE})$.

\begin{tabular}{|c|c|c|c|c|}
\hline \multirow{2}{*}{$\begin{array}{c}\text { Factor }(\mathrm{A}) \\
\text { Organic manure } \\
\text { rate }\end{array}$} & \multicolumn{3}{|c|}{$\begin{array}{c}\text { Factor }(B) \\
\text { Phosphorus Fertilizer rate }\end{array}$} & \multirow[t]{2}{*}{ Mean } \\
\hline & P1 & P2 & P3 & \\
\hline 01 & $18.83 \pm 0.52^{\mathrm{aA}}$ & $20.20 \pm 0.21^{\mathrm{aA}}$ & $19.60 \pm 1.36^{\mathrm{aA}}$ & $19.54 \pm 0.47^{a}$ \\
\hline $\mathbf{O 2}$ & $20.00 \pm 0.15^{\mathrm{aA}}$ & $19.33 \pm 1.44^{\mathrm{aA}}$ & $18.10 \pm 0.67^{\mathrm{aA}}$ & $19.14 \pm 0.54^{\mathrm{a}}$ \\
\hline Mean & $19.42 \pm 0.36^{\mathrm{A}}$ & $19.77 \pm 0.68^{\mathrm{A}}$ & $18.85 \pm 0.75^{\mathrm{A}}$ & \\
\hline \multirow{2}{*}{\multicolumn{2}{|c|}{ LSD at 0.05 for }} & $\mathbf{O}$ & $\mathbf{P}$ & $\mathbf{O} * \mathbf{P}$ \\
\hline & & 1.58 & 1.93 & 2.73 \\
\hline
\end{tabular}

$\mathrm{a}, \mathrm{b} \& \mathrm{c}$ : There is no significant difference $(\mathrm{P}>0.05)$ between any two means, within the same column have the same superscript letter.

A, B \& C: There is no significant difference $(\mathrm{P}>0.05)$ between any two means for the same attribute, within the same row have the same superscript letter.

\section{Conclusion}

It could be application of organic manure at a rate of 50 ton/hectare and the application of $\mathrm{P}$ fertilizer as 630 $\mathrm{kg}$ P-fertilizer /hectare as soil application (which equivalent to $75 \%$ of P-fertilizer required for wheat plant $+210 \mathrm{~kg}$ P-fertilizer/hectare (which equivalent to $25 \%$ of P-fertilizer required for wheat plant) as foliar application significantly increased the productivity of wheat plant under the condition of the studied sandy soil. Also, significantly increased $\mathrm{N}$ content $(\%)$ and increased $\mathrm{P}$ and $\mathrm{K}$ contents $(\%)$ of wheat plants grown on the soil under study.

\section{References}

Belay, A.; A.S. Claassens, F.C. Wehner and J.M. De Beer. 2001. Influence of residual manure on selected nutrient elements and microbial composition of soil under long-term crop rotation. South Afr. J. Plant Soil. 18:1-6.

Brady, N.C. and R.R. Weil. 1999. The Nature and Properties of Soils. Twelve Ed. Prentice-Hall International, Inc. Upper Saddle River. J.USA. 
Chapman, H.D. and P.F. Pratt. 1961. Methods of Analysis for Soil, Plant and Water. Univ. of Calif., USA.

Deksissa, T.; I. Short and J. Allen, 2008. Effect of Soil Amendment with Compost on Growth and Water Use efficiency of Amaranth. In:Proc. the UCOWR/NIWR Annual Conference: International Water Resources: Challenges for the 21st Century and Water Resources Education. July 22-24, 2008, urham, North Carolina.

Hussain, A; M, Rashid and M. Yasin, 1987. Advantages of FYM and its better use. Zarat Nama Lahore. 33: 17-18.

Lambers, H.; Chapin F.S. and Pons, T.L. 2008. Plant physiological ecology. New York: Springer.

Lambers, H.; Shane, M.W; Cramer, M.D; Pearse, S. J. and Veneklaas, E. J. 2006. Root structure and functioning for effcient acquisition of phosphorus: matching morphological and physiological traits. Annals of Botany 98:693713.
Maynard, A. A, 1993. Nitrate leaching from compost amended soil. Compost Science and Ulitilisation, 1: $65-72$.

Page, A.L. R.H. Miller and D.R. Keeney. 1982. Methods of soil analysis. Part 2: Chemical and Microbiological Properties. Second edition. Agronomy J. 9: 2, Am. Soc. Agron. Inc., Soil Sci. Soc. Am. Inc. Pub. Madison, Wisconsin, USA.

Sanchez, C.A. 2007. Phosphorus.In:Handbook of Plant Nutrition.Barker and Pilbeam. CRC PressTaylor and Francis Group. BocaRaton. USA. Chapter 3.pp.51-90.

Singh, C. P.; M. M. Mishra and K.S.Yaday. 1980. Solubilization of inositol $\mathrm{P}$ by thermophilic fungi.Annalsde Microbiologie 131 B:289-296.

White, R. E. 2006. Principles and practice of soil science. The soil as anatural resource. 4th ed. Blackwell Publishing company. Chapter 10.pp.200-229.

Zia, M. S; M. B. Baig and M. B. Tahir, 1998. Soil environment issues and their impact on agricultural productivity of high potential areas of Pakistan. Science Vision, 4: 56-61. 